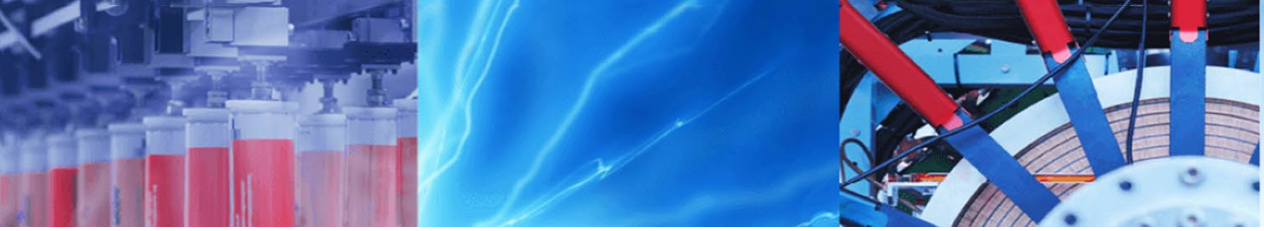

Research Article

\title{
Fabrication of aluminum bipolar plates with Archimedes' screw-shaped channels: a rubber pad forming process assessment
}

\author{
S. J. Hashemi ${ }^{1}$ - Amir H. Roohi ${ }^{2}$ (1)
}

Received: 15 November 2020 / Accepted: 24 February 2021 / Published online: 4 March 2021

(C) The Author(s) 2021 OPEN

\begin{abstract}
Bipolar plates are one of the most important components of polymer membrane fuel cells. In this manuscript, the rubber pad forming of aluminum bipolar plates with Archimedes' screw-shaped channels and draft angle of $90^{\circ}$ has been investigated. Hence, all possible combinations of the process parameters were determined and corresponding experimentations performed in order to investigate the effects of the rubber hardness, punch speed and the hydraulic press force. In this regard, three rubber pads including polyurethane, silicone and natural rubber were used. Channel depth and thinning percentage in the corner of the channel are measured and the effect of each parameter is analyzed. Based on the results, the maximum channel depth was achieved using a silicone pad with a hardness of 60 Shore A. Using a rubber pad with a very high and low hardness number, both, reduces the depth of channel. Furthermore, as the punch speed increases, the channel depth increases and the thinning percentage, as well.
\end{abstract}

Keywords Rubber pad forming process $\cdot$ Bipolar plate $\cdot$ Channel depth $\cdot$ Thinning $\cdot$ Process assessment

\section{Introduction}

Proton-exchange membrane fuel cells are one of the devices to generate DC electric current without causing chemical contamination. The input material, which is supplied to these cells is usually hydrogen and air (oxygen). As a result of a chemical reaction that takes place inside the cell, the electrons move. The by-product of water is also yielded within the fuel cell. One of the most important components of these cells is bipolar plates, on which there are channels for passing reactive gases as well as the water. The longer the channel path length of the bipolar plates, the higher the probability of the chemical reaction. Therefore, the higher electrical current intensity could be produced. Different materials are used to make bipolar plates, most commonly graphite. But the graphite has a low machinability, impact and bending strengths [1]. Thus, the use of metals and composites for construction of bipolar plates has been considered [2].

Metallic bipolar plates are manufactured using a variety of approaches, including hydroforming, electroforming, casting, powder metallurgy, stamping and machining [3]. Nikam [4] et al. studied the bipolar plates with parallel hemispherical channels forming using a manual operating tube wringer (i.e. rollers and handle). Dundar et al. [5] compared the corrosion resistance of metallic bipolar plates as the products of stamping and hydroforming processes. They determined a process window to achieve the highest corrosion resistance. As well, by comparing two processes of stamping and hydroforming in the fabrication of bipolar plates with different materials, Mahabunphachai et al. [6] presented that the hydroforming products have higher surface quality. Turan et al. [7] examined the effect of punch speed in the stamping process, and the

$凶$ Amir H. Roohi, Amir.roohi@qiau.ac.ir| 'Department of Mechanical Engineering, Faculty of Enghelab-e Eslami, Tehran Branch, Technical and Vocational University (TVU), Tehran, Iran. ${ }^{2}$ Department of Mechanical Engineering, Faculty of Industrial and Mechanical Engineering, Qazvin Branch, Islamic Azad University, Qazvin, Iran. 
pressure rate in the hydroforming of bipolar metal sheets. They showed that plates produced by stamping process have higher electrical contact resistance characteristics, compared to hydroforming products. Hu et al. [8] studied the stamping process of ss304 bipolar plates. They found that low punch speed causes a wrinkling in the products, while high speeds cause a crack initiation. Koo et al. [9] investigated the effect of applying pulsating force on the formability of the sheet in the stamping process of bipolar plates. According to the results of Park et al. [10], when a primary heat treatment is applied on the stainless steel sheets, a higher bipolar channel depth could be achieved during the stamping process. Also, the use of dynamic load, rather than static load, creates a greater channel depth. Xu et al. [11] conducted the hydroforming process of thin copper sheet metals to produce bipolar plates, after investigating the effect of grain sizes on the formability of the sheets. On the other hand, the rubber pad forming is reported as a practical and a suitable method for producing metal bipolar plates [12]. In this process, the rubber pad replaces the punch in the stamping process and thus, the tool cost and production cost is reduced [13]. Due to the hyperelastic deformation of the rubber pad used, a uniform distribution of the pressure on all surfaces of the sheet is possible during the forming process [14]. The parts made with this process have high surface quality and dimensional accuracy [15]. So far, numerous research contributions focusing on this process have been published: Dirikolu et al. [16] investigated the influences of different parameters such as rubber hardness, coefficient of friction and geometrical characteristics of the die on the bipolar plates production through rubber pad forming. Liu et al. [17] studied the fabrication of bipolar plates channel with two different deformation styles, i.e. convex and concave, using rubber pad forming. Based on their results, the production of a bipolar plate with a channel width to the rib width ratios less than one in a convex state is quite appropriate. Peng et al. [18] numerically and experimentally studied the effects of hardness number of the rubber, and the friction coefficient on the rubber pad forming of stainless steel bipolar plates. Lim et al. [19] studied the effect of various parameters, such as the initial sheet thickness, the thickness of the pad and the press force on the quality of the produced bipolar plates. Jeong et al. [14] showed that by increasing the rubber pad thickness and the punch speed, the channel depth of the bipolar plates increases. While, an increase in the hardness of the pad caused the final depth to be decreased. Kolahdooz et al. [20] performed a three-dimensional finite element simulation of the rubber pad forming process, which showed that the maximum thinning occurs in the corners of the bipolar plates channel.

SN Applied Sciences

A SPRINGER NATURE journal
Although, numerous investigations have been perform to specify the effects of different process parameters on the rubber pad forming of bipolar plates, a lack of experimental studies on the forming of bipolar plates with an Archimedes' screw-shaped channel has been found. A schematic image of such a channel pattern is shown in Fig. 1. In this paper, the rubber pad forming of aluminum bipolar plates with the draft angle of $90^{\circ}$ is carried out. It would be a big challenge to prepare such a high draft angle for the channel walls. In order to produce a bipolar plate with the maximum channel depth and limited thinning percentage, three different types of rubber have been utilized in the rubber pad forming experimentations. The rubbers used in this study are: polyurethane, silicone and natural rubber. Hence, a full factorial design of experiment was conducted and the influences of effective process parameters including rubber type, press force and punch speed were evaluated. As a result, the channel depth of the formed samples and the maximum thinning percentage were measured, and the effect of each parameter on the products was investigated. Finally, an equation was derived in order to predict the channel depth and the thinning percentage values as a function of above-mentioned parameters.

\section{Experimental procedure}

In this study, the metal sheets used to produce bipolar plates are of aluminum 1050 alloy with an initial thickness of 300 microns. For conducting the experimentations, the rubber pad is firstly located inside the supporting bed (Fig. 2a) and then, the aluminum sheet is placed on it. Note that the depth of the lower die and the thickness of the rubber pad are $60 \mathrm{~mm}$ and $40 \mathrm{~mm}$, respectively.

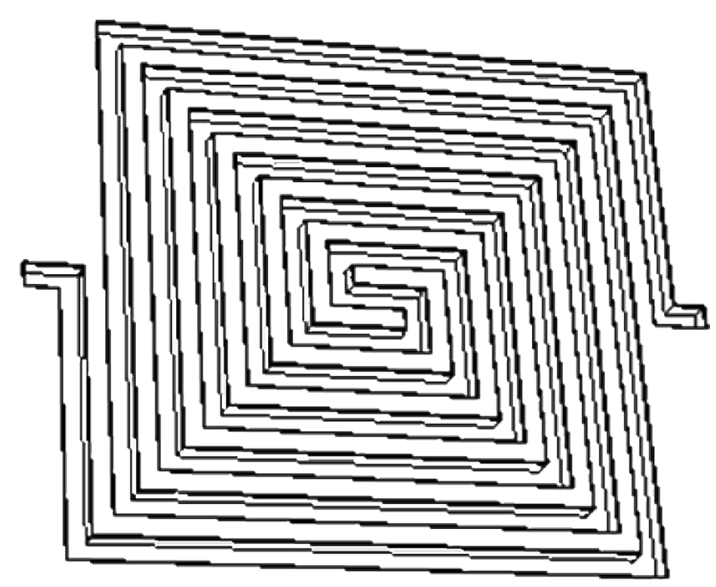

Fig. 1 A schema of bipolar plate with an Archimedes' screw-shaped channels 

cess; $\mathbf{b}$ end of the process
Fig. 2 a Initiation of the pro-

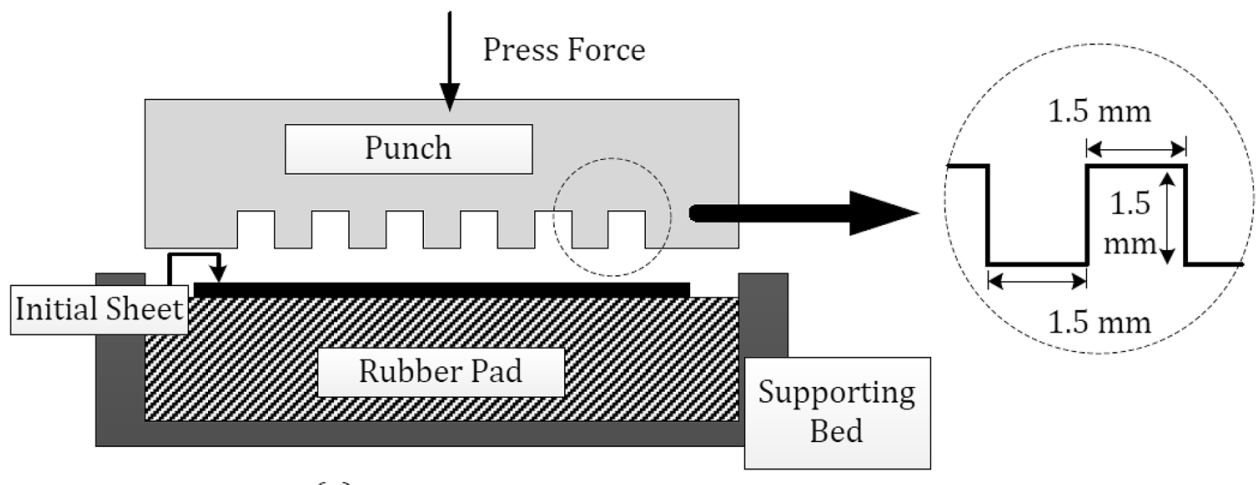

(a)

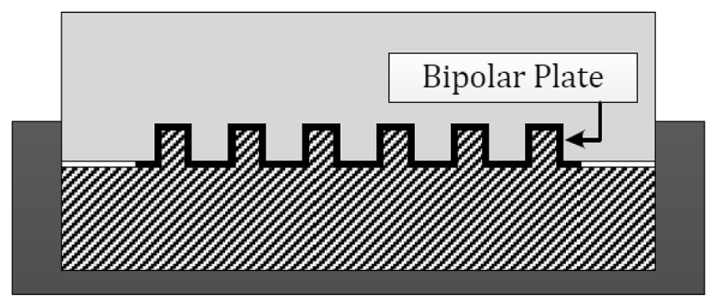

(b)

In the next step, a steel forming punch is pressed on the sheet with the application of a hydraulic press (Fig. 2b), and the sheet accepts the shape of the channels on the punch surface. The punch and lower die are made of steel DIN Ck45. Electric Discharge Machining (EDM) process has been used to produce the forming channels on the punch, and a lubricant is utilized during the forming process in order to reduce frictional forces between the sheet and the punch surface. The actual punch and arrangement of process setup is shown in Fig. 3. It's worth mentioning that the punch speed is controllable by the press controlling system. Three different rubber pads, i.e. polyurethane, silicone and natural rubber are used through the experiments. The hardness number of each pad is listed in Table 1 (for simplicity, the rounded numbers are shown in the Table, instead of measured hardness numbers of $50.1,60.2$ and 89.9, respectively). Also, the compressive stress-strain curve of these three rubbers are illustrated in Fig. 4. Digital micrometers, of the point micrometer type, with an accuracy of $0.001 \mathrm{~mm}$ have been used to measure the channel depth and the thickness of the formed products. In order to determine the maximum thinning percentage, the sheet thickness was measured at 5 different points in the channel corner region, and the minimum value was used to calculate the thinning.

\section{Results and discussion}

Because the geometrical characteristics of the forming punch are kept constant, three different process parameters, such as rubber pad hardness number, punch speed and force have been considered. In order to determine the effects of these parameters on the channel depth and thinning percentage, three different levels are defined for each, as shown in Table 2. It's worth mentioning that the parameter range is specified in a way that all the possible combinations of the parameters lead to the products with an accepted forming value (i.e. channel depth), and without experiencing any defects (i.e. cracking, severe thinning, and etc.). In fact, the maximum press force is limited considering the formability of the aluminum sheet. In the case of excessive applied forces, the rupture occurs in the product (Fig. 5). It should be noted that the onset of rupture for all defected specimens was from the central channel; because of the existence of frictional forces as well as an insufficient material feed in this region. Also, the most thinning is observed in the central region due to the applied tensile stresses from both sides.

\subsection{The process characterization}

An example of bipolar plates, which formed with a natural rubber pad and the punch speed of $1.3 \mathrm{~mm} / \mathrm{s}$ is shown in Fig. 6. It's obvious if the press force is low, the plastic deformation of the sheet is low. Thus, the springback reduces the depth of the formed channel. It is worth mentioning that the effect of springback on the formed channel depth 
Fig. 3 Forming Setup, and the corresponding punch shape

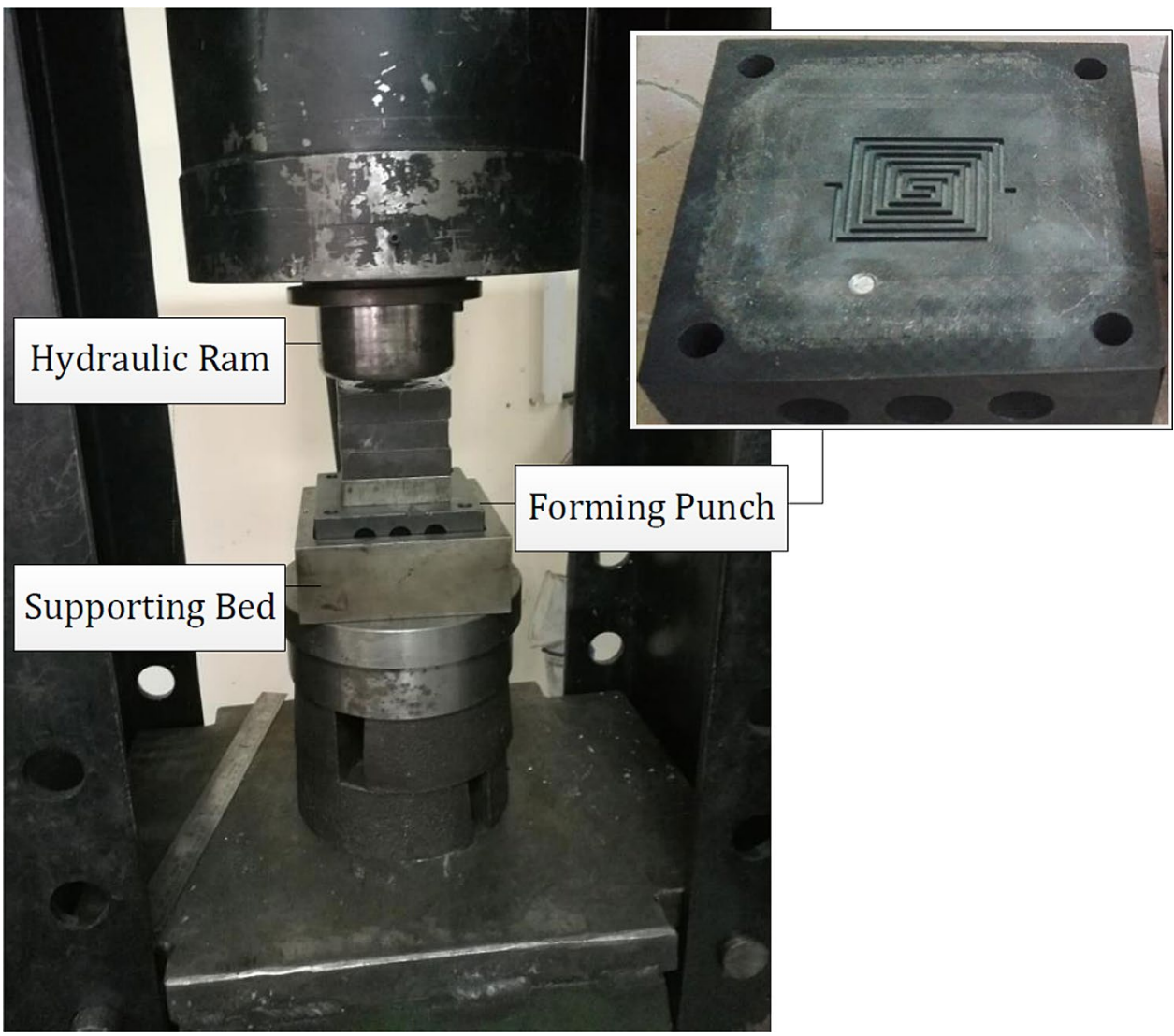

Table 1 Hardness number of the used rubber pads

\begin{tabular}{ll}
\hline Pad material & $\begin{array}{l}\text { Hardness } \\
\text { (Shore A) }\end{array}$ \\
\hline Natural rubber & 50 \\
Silicone & 60 \\
Polyurethane & 90 \\
\hline
\end{tabular}

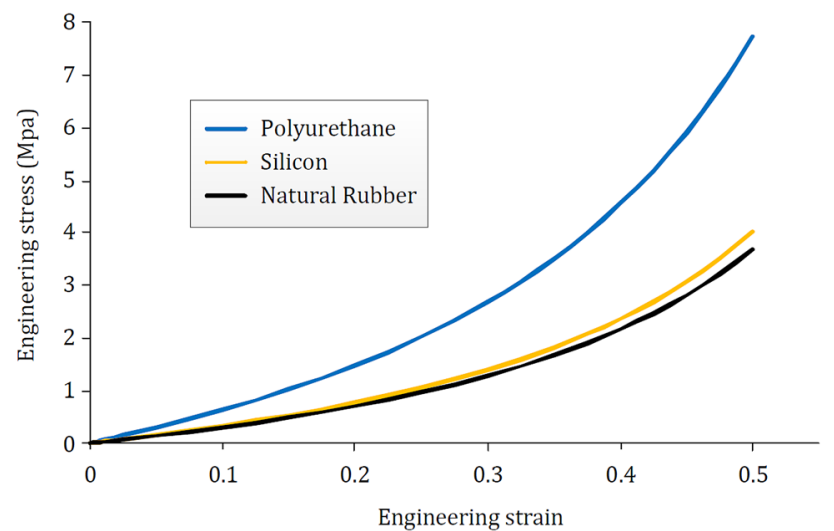

Fig. 4 Compressive stress-strain curve for three used rubbers
Table 2 Process parameters and the defined levels

\begin{tabular}{lllll}
\hline Parameters & Unit & 1st level & Center point & 3rd level \\
\hline Press force & (ton) & 30 & 36 & 42 \\
Punch speed & (mm/s) & 0.8 & 1.3 & 1.8 \\
\hline
\end{tabular}

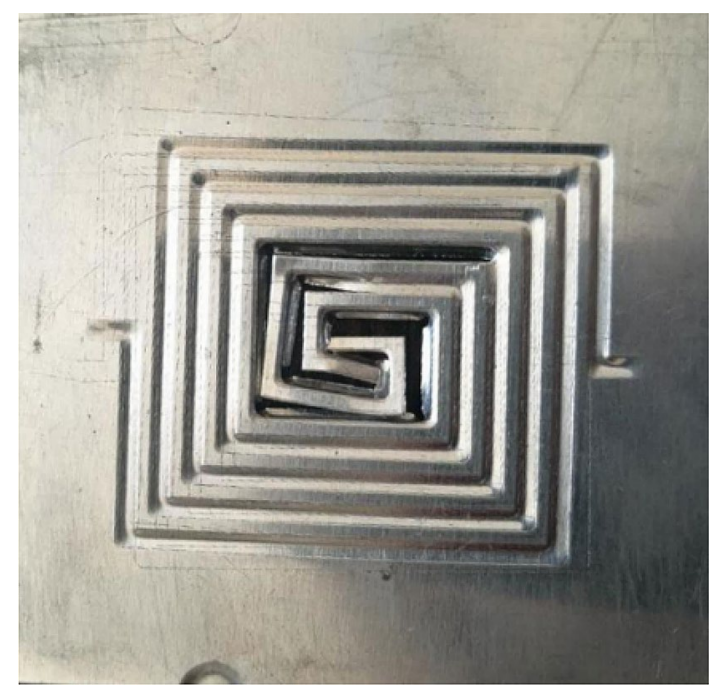

Fig. 5 A ruptured produced sample due to the applied excessive press forces; polyurethane pad, punch speed of $8 \mathrm{~mm} / \mathrm{s}$, press force of 50 ton 


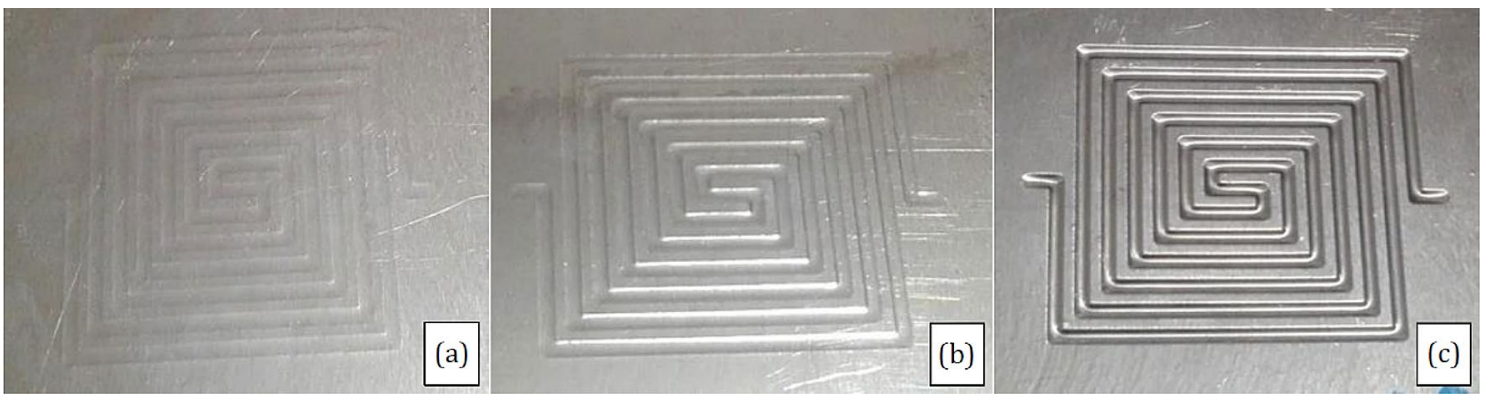

Fig. 6 Bipolar plates formed with a natural rubber and the punch speed of $1.3 \mathrm{~mm} / \mathrm{s}$, and press forces of a 30 ton; $\mathbf{b} 36$ ton; and $\mathbf{c} 42$ ton

Table 3 Experimental results of the rubber-pad forming process

\begin{tabular}{|c|c|c|c|c|c|}
\hline Exp. No & Load (ton) & $\begin{array}{l}\text { Velocity } \\
(\mathrm{mm} / \mathrm{s})\end{array}$ & $\begin{array}{l}\text { Hardness } \\
\text { (Shore A) }\end{array}$ & $\begin{array}{l}\text { Depth } \\
(\mathrm{mm})\end{array}$ & $\begin{array}{l}\text { Thinning } \\
\text { (\%) }\end{array}$ \\
\hline 1 & 30 & 0.8 & 50 & 0.3 & 9.9 \\
\hline 2 & 30 & 1.3 & & 0.31 & 10.05 \\
\hline 3 & 30 & 1.8 & & 0.32 & 10.1 \\
\hline 4 & 36 & 0.8 & & 0.35 & 11.9 \\
\hline 5 & 36 & 1.3 & & 0.41 & 14.75 \\
\hline 6 & 36 & 1.8 & & 0.43 & 15.5 \\
\hline 7 & 42 & 0.8 & & 0.47 & 17.6 \\
\hline 8 & 42 & 1.3 & & 0.55 & 22.4 \\
\hline 9 & 42 & 1.8 & & 0.52 & 20.5 \\
\hline 10 & 30 & 0.8 & 60 & 0.3 & 8.9 \\
\hline 11 & 30 & 1.3 & & 0.32 & 9.8 \\
\hline 12 & 30 & 1.8 & & 0.31 & 9.2 \\
\hline 13 & 36 & 0.8 & & 0.38 & 13.1 \\
\hline 14 & 36 & 1.3 & & 0.43 & 15.2 \\
\hline 15 & 36 & 1.8 & & 0.45 & 16.9 \\
\hline 16 & 42 & 0.8 & & 0.48 & 18.1 \\
\hline 17 & 42 & 1.3 & & 0.55 & 23.4 \\
\hline 18 & 42 & 1.8 & & 0.54 & 21.5 \\
\hline 19 & 30 & 0.8 & 90 & 0.3 & 9.7 \\
\hline 20 & 30 & 1.3 & & 0.31 & 10.1 \\
\hline 21 & 30 & 1.8 & & 0.32 & 10.8 \\
\hline 22 & 36 & 0.8 & & 0.34 & 12 \\
\hline 23 & 36 & 1.3 & & 0.4 & 14.9 \\
\hline 24 & 36 & 1.8 & & 0.41 & 15.1 \\
\hline 25 & 42 & 0.8 & & 0.45 & 16.5 \\
\hline 26 & 42 & 1.3 & & 0.51 & 20.7 \\
\hline 27 & 42 & 1.8 & & 0.53 & 22.4 \\
\hline
\end{tabular}

is not measured, however the minimum considered force in this study (i.e., 30 ton) is selected in a way to create a minimum depth of $0.3 \mathrm{~mm}$ using all three rubber types.

After the forming process is accomplished, the depth of the central channel and the amount of thinning percentage at the corner of the channel were measured (Table 3). In fact, all nine possible combinations of the experiments are performed for each of the three polyurethane, silicone, and natural rubber pads (i.e. 27 total experiments). Note that the occurrence of the highest thinning values for all samples is the reason for the selection of the central channel as a criterion for the comparison. Figure 5 also confirm that the rupture is begun from the central channel. The cross-section of the bipolar plates central channel, and measuring the channel depth and the minimum thickness is shown in Fig. 7. Based on the analysis of variance of the experimental data, two polynomial models were specified for the maximum channel depth and the thinning percentage values, regarding three different rubber pads, as follows:

Depth $=A+0.01 \times F+0.13 \times v+0.0039 \times F \times v-0.08 \times v^{2}$

Thinning $=\mathrm{B}+0.49 \times \mathrm{F}+5.33 \times \mathrm{v}+0.29 \times \mathrm{F} \times \mathrm{v}-5.09 \times \mathrm{v}^{2}$

In the above equations, $\mathrm{A}$ is the constant value for the channel depth equation (i.e. $-0.21,-0.20$, and -0.22 for natural, silicone and polyurethane rubber pads, respectively), $B$ is the constant value for the thinning equation (i.e. $-14.25,-13.88$, and -14.31 for natural, silicone and polyurethane rubber pads, respectively), $F$ is press force [ton], and $v$ is punch speed (mm/s). Referring Fig. $8 a$, $b$, there is an accurate accordance between the actual results and the predicted data using the above-mentioned models (Eqs. 1 and 2). Furthermore, the analysis of the variance data for both predictive models is listed in Table 4. According to the analysis of variance (ANOVA) of the results, the model with the maximum order is selected; so that all model terms have a significant effect on the result ( $P$-value less than 0.05). It is worth mentioning that according to Fig. 4, the polyurethane pad requires much higher stress to have an elastic strain equal to other two pads (especially as the desired strain increases), but this difference is relatively small with respect to low elastic strain values. Similarly, as is specified in Table 3, the channel depth at low press forces is almost in the same order for different pad types, 
Fig. 7 Measurement of channel depth and thinning in the central channel
Fig. 8 Predicted-actual curve for a depth of channel; $\mathbf{b}$ thinning percentage
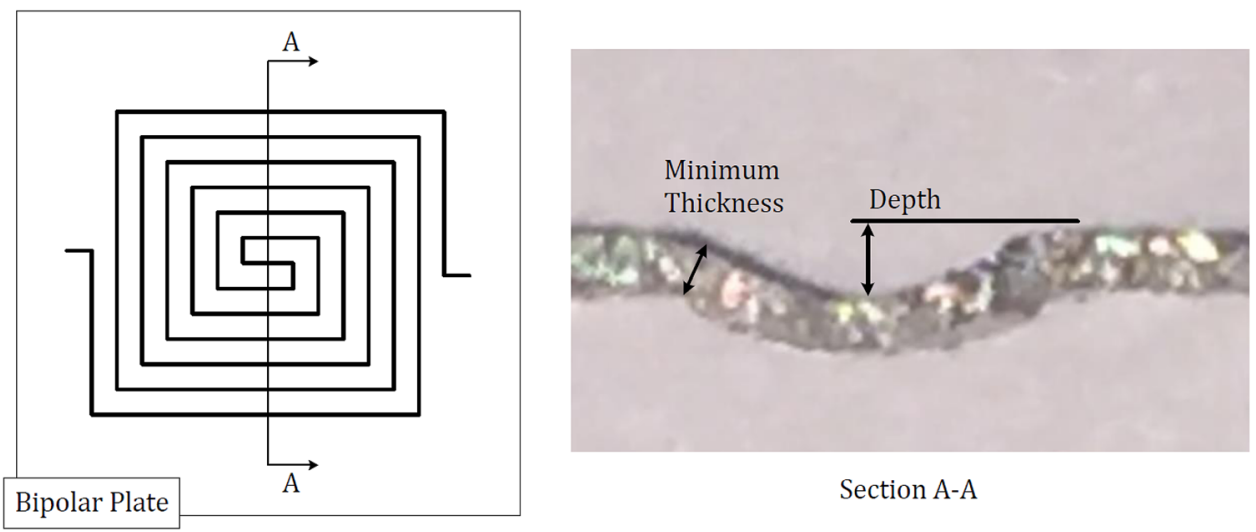

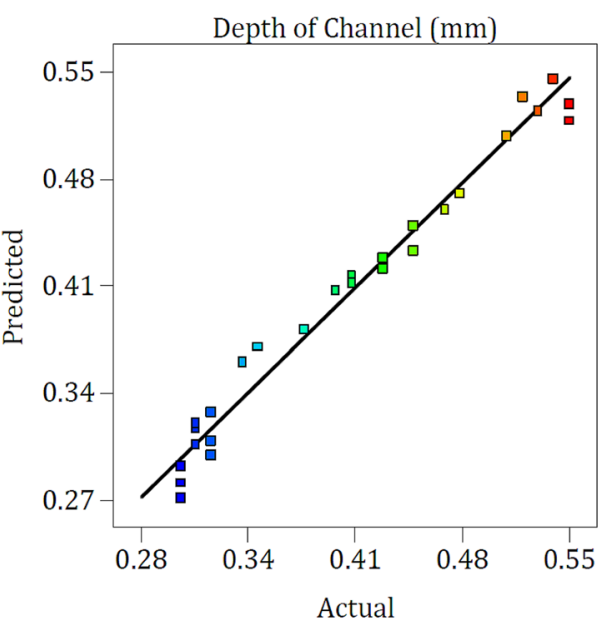

(a)

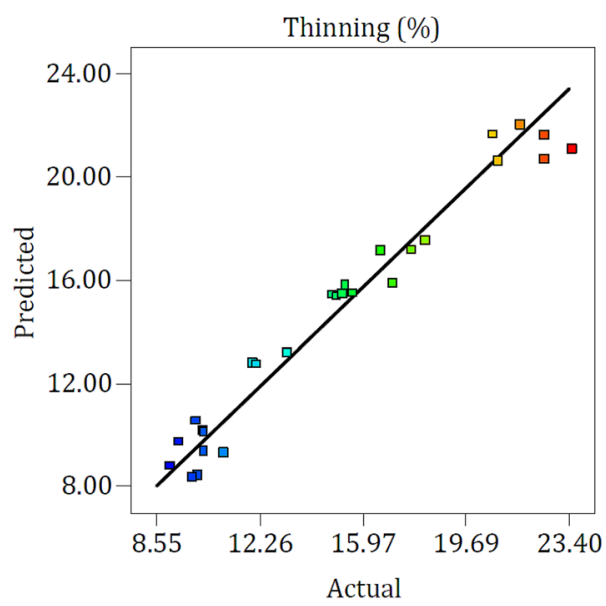

(b)
Table 4 Analysis of variance of the derived model

\begin{tabular}{llc}
\hline & Channel depth & $\begin{array}{l}\text { Thinning } \\
\text { percentage }\end{array}$ \\
\hline SD & 0.016 & 1.05 \\
R-squared & 0.98 & 0.96 \\
Adj. R-squared & 0.97 & 0.95 \\
Predicted R-squared & 0.96 & 0.93 \\
Adeq. precision & 34.34 & 25.58 \\
\hline
\end{tabular}

however, as the pad pressure increases the channel depth is more significant if the polyurethane pad is used rather than other two pads.

\subsubsection{Depth of channel}

The effect of input parameters on the channel depth of bipolar plates produced by the rubber pad forming is shown in Figs. 9, 10 and 11. Figure 9 represents the relation between press force and depth of channel for the silicone rubber pad. The same trend is also observed for

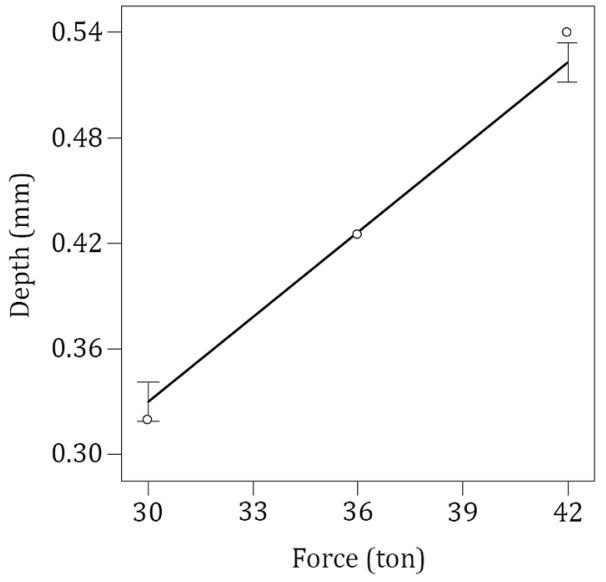

Fig. 9 Effect of press force on the channel depth (for silicone rubber pad)

two other pads. Results show that an increase in the press force increases the channel depth with a linear model. In fact, with a $40 \%$ increase in the press force, an almost $60 \%$ enhanced channel depth is observed. By increasing the 


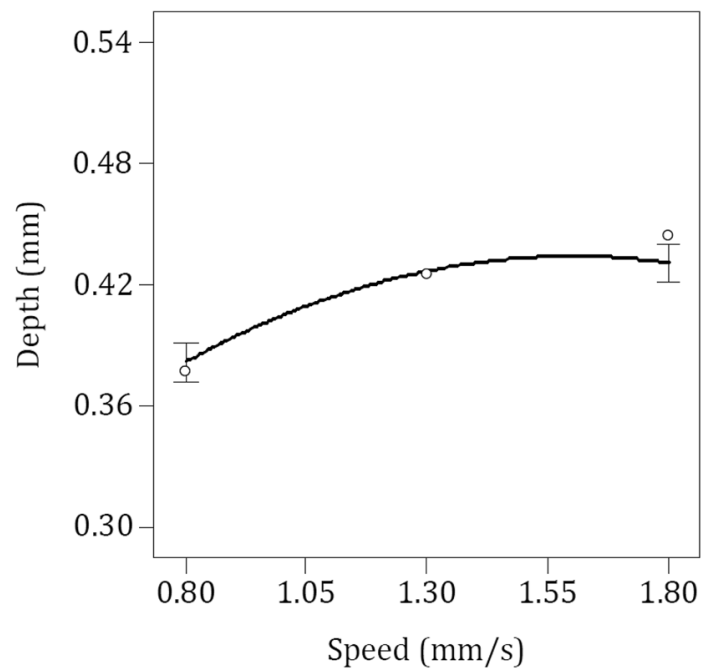

Fig. 10 Effect of punch speed on the channel depth (for silicone rubber pad)

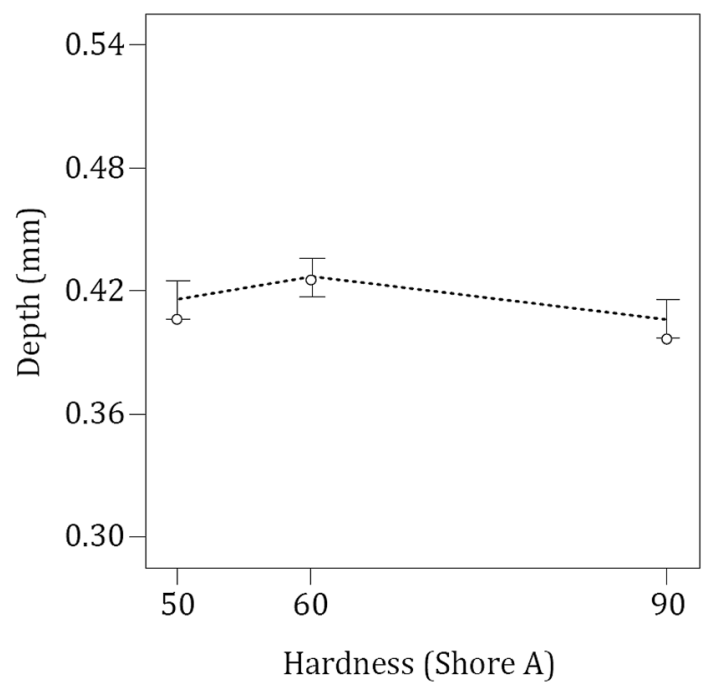

Fig. 11 Effect of rubber hardness on the channel depth

press force, the pressure on the rubber pad is significantly increased, which leads to a bending in places where the sheet is not in contact with the die, and thus the sheet is drawn into the die. According to Fig. 10, the depth of channel is increased with increasing the press speed. However, the effect of speed on the depth is nonlinear (i.e. a second order equation), and the curve slope decreases with increasing speed. In the case of each used pad type in the forming process and under different press forces (including 9 modes), the depth of the formed channel increases with increasing the punch speed. This phenomenon can be attributed to the increase in elastic energy stored in the rubber pad, and hence the increase in pressure applied to the sheets. In fact, as the punch speed increases the velocity of elastic deformation and consequently the applied pressure to the aluminum sheet increases, and the channel depth also increases. Figure 11 shows that there is an optimum value for rubber pad hardness in order to achieve the maximum depth. As shown in the figure, with increasing the hardness number from 50 to 60 shore $A$ (i.e. natural rubber to silicone), the channel depth is increased and then, the depth shows a decrease with increasing the hardness number to 90 (polyurethane). This could be attributed to the differences of elastic deformation magnitude of the rubber pads when applying the press force. In fact, when the rubber pad hardness number decreases, applying the press force exerts high values of elastic deformation on the pad. Thus, due to the fact that the inner pressure of the pad is not raised enough, small forces are applied into the sheet, resulting in a lower channel depth. However, in this case the channel depth could be compensated by increasing the press force. On the other hand, if the hardness of the rubber pad is too high, there would not be much deformation in it; hence, the pad doesn't push itself into the sheet and the depth of channel decreases again.

The interactive effect of press force and punch speed on the channel depth is also shown in Fig. 12. Accordingly, choosing the high press forces leads to the higher depth of channel, even if lower speeds are selected. On the contrary, if the speed is high, high channel depths need higher press forces. Thus, press force is more effective parameter on the process output, compared to the punch speed, even though both have a direct relationship with the bipolar plate channel depth.

\subsubsection{Thinning percentage}

Figures 13, 14 and 15 illustrates the effects of process parameters on the thinning percentage. As it's obvious,

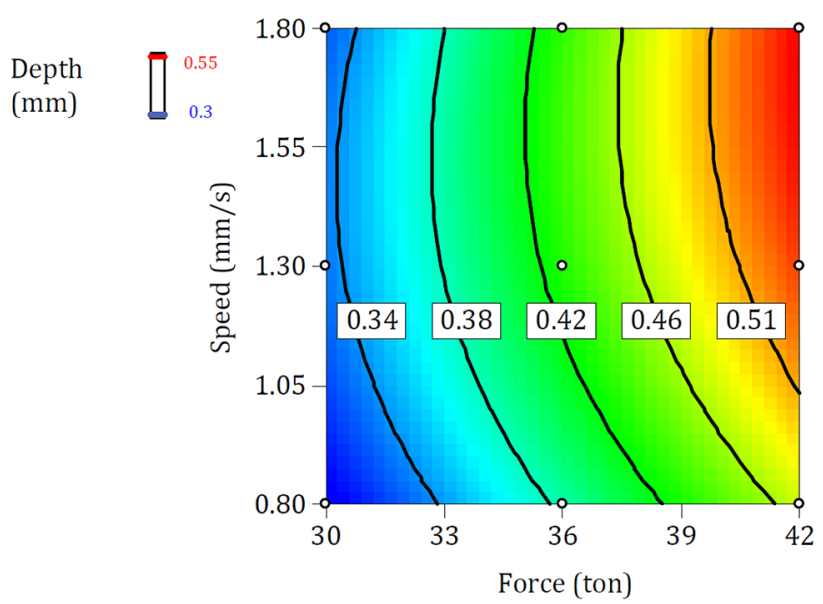

Fig. 12 Interactive effects of force and speed on the channel depth 


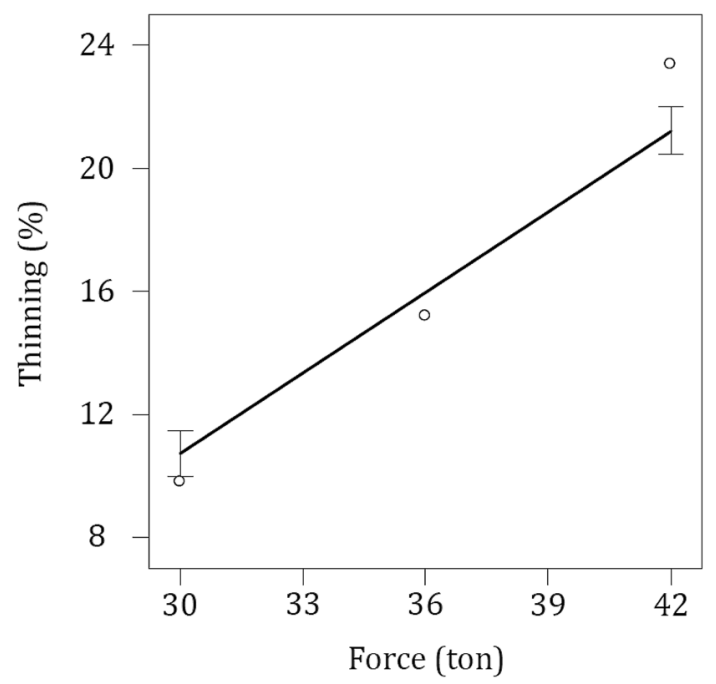

Fig. 13 Effect of press force on the thinning (for silicone rubber pad)

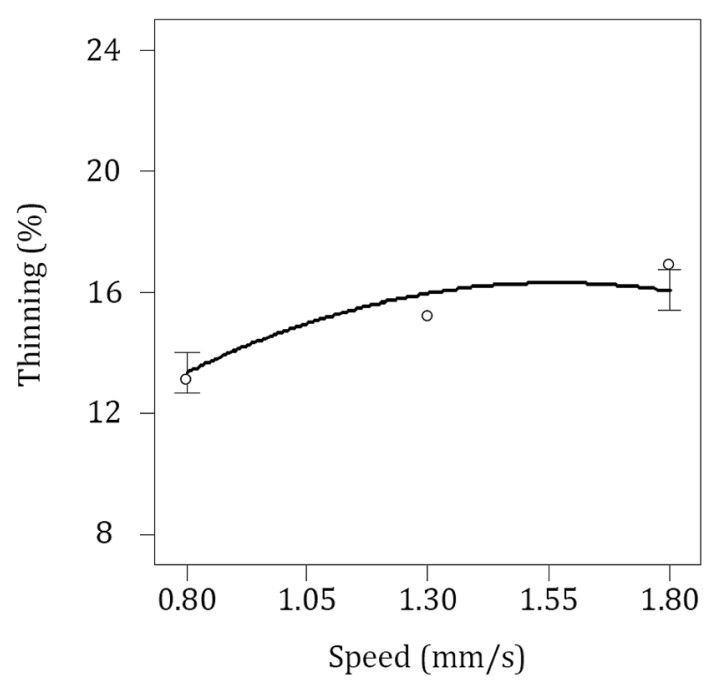

Fig. 14 Effect of punch speed on the thinning (for silicone rubber pad)

the press force is more effective on the thinning at the corners of the central channel, compared to other parameters. This corresponds to the effect of the same parameters on the depth of the central channel. Figure 13 shows that with a press force increasing from 30 to 42 tons, the thinning is nearly doubled. This is due to the friction forces of the sheet with the die surfaces and rubber pad as well. As shown in Fig. 16, in the area where the sheet is in contact with the die, increasing in the press force increases the friction force, and the material flow into the channel is restricted. Furthermore, the friction between the sheet and the rubber pad will prevent the large deformation of the sheet and as a result, the channel corner (i.e. the point

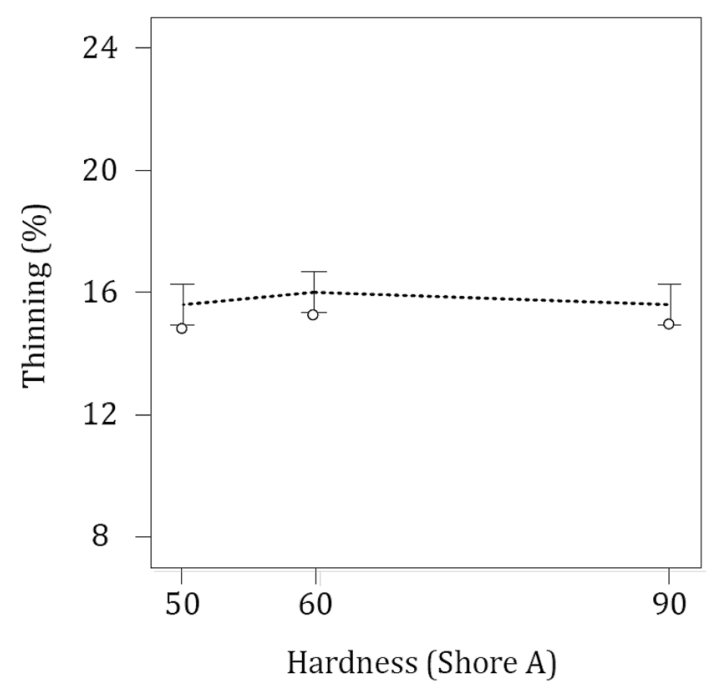

Fig. 15 Effect of rubber hardness on the thinning

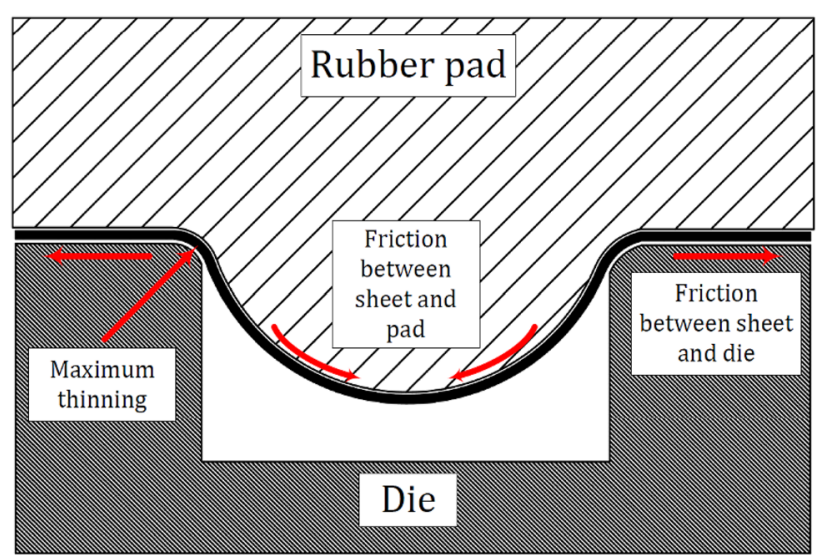

Fig. 16 Friction forces when applying the press force

where the direction of the friction force is reversed) experiences high values of thinning. Figure 14 shows that the thinning percentage is increased slightly with the increase in the punch speed, which is in accordance with a slight increase in the depth of channel. Finally, the highest value of thinning was obtained as the hardness of the rubber is equal to 60 Shore A (Fig. 16). By comparing Figs. 11 and 15 , it is shown that the effect of pad hardness on the channel depth and thinning is approximately the same. Multi-objective optimization results show that in order to achieve the highest depth of channel, and simultaneously maintain the thinning percentage in the safe range, the process parameters selection could be as follows: press 


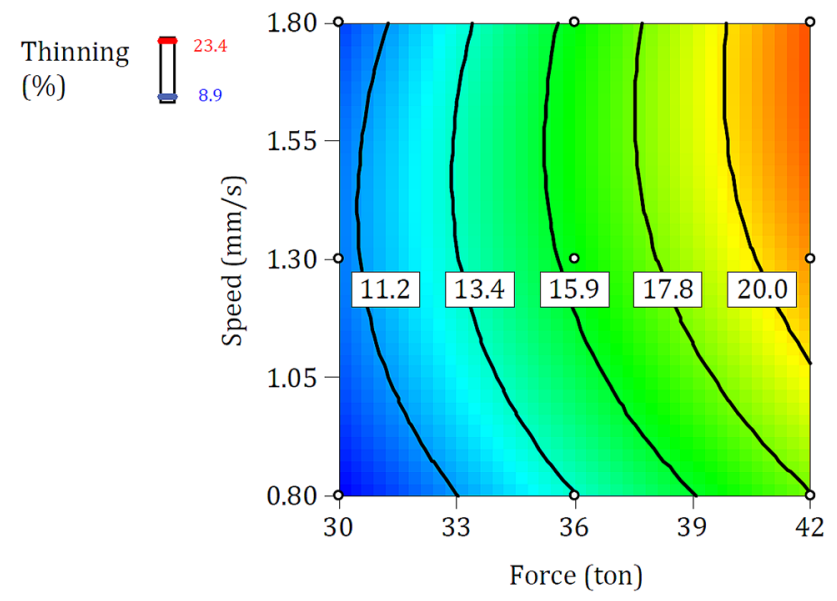

Fig. 17 Interactive effects of force and speed on the thinning force of 40 tons, punch speed of $0.8 \mathrm{~mm} / \mathrm{s}$, and pad hardness of 60 Shore $A$ (i.e. silicone rubber pad). In this case, the channel depth is almost $0.45 \mathrm{~mm}$, and the thinning is $16.3 \%$. It is worth mentioning that for the multi-objective optimization, a multiple response method entitled desirability has been used using Design-Expert optimization package. Briefly, above-stated technique makes use of an objective function, called the desirability function, which reflects the desirable range for each response (the optimization technique is explained in extra info in [21]). Furthermore, the depth of all channels in the optimum sample was measured. As is observed, the depth of all channels is not equal and the highest value is related to the central channel. This indicates that there is more pressure exerted by the rubber pad at the center of the sheet. However, the difference in the channel heights (i.e., side channel vs. central channel) was about $5 \%$. One of the main reasons for the pressure drop in the side regions is attributed to the frictional forces between the rubber pad and the die wall.

Figure 17 illustrates the interactive effect of the press force and punch speed on the thinning. As it's obvious, the speed does not have much effect on the result, when small forces are selected to decrease the product thinning. However, in high press forces, the thinning could be restricted by decreasing speed.

\section{Conclusions}

In this manuscript, the forming of aluminum bipolar plates with Archimedes' screw-shaped channels was investigated using different rubber pads. By choosing press force, punch speed and pad hardness as the main input factors a design of experiment has been conducted. Analysis of the experimental results leads to the predictive models, which predict the depth of channel and the thinning of the formed bipolar plates. Results show that the press force is the most important factor on the depth of channel and thinning. The maximum channel depth was achieved using the maximum force and speed and the usage of silicone rubber pad. As the depth of channel increases, thinning is strongly increased, which is mainly due to the friction of the sheet with the die and the rubber pad, as well. Regarding the interaction of the parameters, the maximum press force and speed must be used in order to achieve the maximum depth of channel. The effect of the press force on the channel depth is linear, so that by increasing $73.3 \%$ of the press force for all three types of rubber pads, on average, has increased the channel depth by the factor of almost $80 \%$. However, the limited formability of the aluminum sheets at room temperature would not allow the press force to be further increased to achieve higher depths.

Due to the fact that a rubber with the desired hardness number are not available (i.e., each rubber has a unique hardness number, and it is difficult/impossible to implement a rubber based on an arbitrary hardness number.), thus it is not possible to optimize the process based on the hardness number of the rubber. Although the use of elevated temperature enhances the formability of aluminum sheets, but it also softens the rubbers. However, using a suitable rubber with a high-temperature resistance leads to a higher quality bipolar plate products.

Funding The authors received no financial support for the research, authorship, and/or publication of this article.

\section{Declarations}

Conflict of interest The authors declare no conflict of interest.

Open Access This article is licensed under a Creative Commons Attribution 4.0 International License, which permits use, sharing, adaptation, distribution and reproduction in any medium or format, as long as you give appropriate credit to the original author(s) and the source, provide a link to the Creative Commons licence, and indicate if changes were made. The images or other third party material in this article are included in the article's Creative Commons licence, unless indicated otherwise in a credit line to the material. If material is not included in the article's Creative Commons licence and your intended use is not permitted by statutory regulation or exceeds the permitted use, you will need to obtain permission directly from the copyright holder. To view a copy of this licence, visit http://creativecommons. org/licenses/by/4.0/.

\section{References}

1. Dhakate S, Sharma S, Borah M, Mathur R, Dhami T (2008) Expanded graphite-based electrically conductive composites as bipolar plate for PEM fuel cell. Int J Hydrog Energy 33(23):7146-7152 
2. Shimpalee S, Lilavivat $\mathrm{V}, \mathrm{McCrabb} \mathrm{H}$, Khunatorn $\mathrm{Y}$, Lee H-K, Lee W-K, Weidner J (2016) Investigation of bipolar plate materials for proton exchange membrane fuel cells. Int J Hydrog Energy 41(31):13688-13696

3. Mehta V, Cooper JS (2003) Review and analysis of PEM fuel cell design and manufacturing. J Power Sources 114(1):32-53

4. Nikam VV, Reddy RG (2006) Corrugated bipolar sheets as fuel distributors in PEMFC. Int J Hydrogen Energy 31(13):1863-1873

5. Dundar F, Dur E, Mahabunphachai S, Koc M (2010) Corrosion resistance characteristics of stamped and hydroformed proton exchange membrane fuel cell metallic bipolar plates. J Power Sources 195(11):3546-3552

6. Mahabunphachai S, Cora ÖN, Koç M (2010) Effect of manufacturing processes on formability and surface topography of proton exchange membrane fuel cell metallic bipolar plates. J Power Sources 195(16):5269-5277

7. Turan C, Cora ÖN, Koç M (2011) Effect of manufacturing processes on contact resistance characteristics of metallic bipolar plates in PEM fuel cells. Int J Hydrog Energy 36(19):12370-12380

8. Hu Q, Zhang D, Fu H, Huang K (2014) Investigation of stamping process of metallic bipolar plates in PEM fuel cellnumerical simulation and experiments. Int J Hydrog Energy 39(25):13770-13776

9. Koo J, Kim H, Jeon Y, Kang C (2014) Formability evaluation of microchannels of aluminum bipolar plate stamped under pulsating load. J Eng Mater Technol 136(4):041004

10. Park WT, Jin CK, Kang CG (2016) Improving channel depth of stainless steel bipolar plate in fuel cell using process parameters of stamping. Int J Adv Manuf Technol 87(5-8):1677-1684

11. Xu Z, Peng L, Yi P, Lai X (2019) An investigation on the formability of sheet metals in the micro/meso scale hydroforming process. Int J Mech Sci 150:265-276

12. Son C-Y, Jeon Y-P, Kim Y-T, Kang C-G (2012) Evaluation of the formability of a bipolar plate manufactured from aluminum alloy Al 1050 using the rubber pad forming process. Proc Inst Mech Eng Part B: J Eng Manuf 226(5):909-918
13. Jin CK, Jeong MG, Kang CG (2014) Fabrication of titanium bipolar plates by rubber forming and performance of single cell using TiN-coated titanium bipolar plates. Int J Hydrogen Energy 39(36):21480-21488

14. Jeong M-G, Jin C-K, Hwang G-W, Kang C-G (2014) Formability evaluation of stainless steel bipolar plate considering draft angle of die and process parameters by rubber forming. Int $J$ Precis Eng Manuf 15(5):913-919

15. Liu Y, Hua L (2010) Fabrication of metallic bipolar plate for proton exchange membrane fuel cells by rubber pad forming. J Power Sources 195(11):3529-3535

16. Dirikolu MH, Akdemir E (2004) Computer aided modelling of flexible forming process. J Mater Process Technol 148(3):376-381

17. Liu Y, Hua L, Lan J, Wei X (2010) Studies of the deformation styles of the rubber-pad forming process used for manufacturing metallic bipolar plates. J Power Sources 195(24):8177-8184

18. Peng L, Hu P, Lai X, Ni J (2010) Fabrication of metallic bipolar plates for proton exchange membrane fuel cell by flexible forming process-numerical simulations and experiments. J Fuel Cell Sci Technol 7(3):031009

19. Lim S, Kim Y, Kang C (2013) Fabrication of aluminum 1050 microchannel proton exchange membrane fuel cell bipolar plate using rubber-pad-forming process. Int J Adv Manuf Technol 65(1-4):231-238

20. Kolahdooz R, Asghari S, Rashid-Nadimi S, Amirfazli A (2017) Integration of finite element analysis and design of experiment for the investigation of critical factors in rubber pad forming of metallic bipolar plates for PEM fuel cells. Int J Hydrog Energy 42(1):575-589

21. Software D-E Help Section

Publisher's Note Springer Nature remains neutral with regard to jurisdictional claims in published maps and institutional affiliations. 